\title{
Effects of beach replenishment on intertidal invertebrates: a 15-month, eight beach study.
}

Tyler Wooldridge, Heather J. Henter, Joshua R. Kohn

University of California San Diego, La Jolla, CA, USA, 92093-0116

Corresponding author: Joshua Kohn jkohn@ucsd.edu, +18585348233 
1

2

3

4

\section{Abstract}

Beach replenishment is an increasingly popular means to remediate coastal erosion, but no consensus exists regarding how long replenishment affects sandy beach intertidal invertebrates, key components of beach ecosystems. We monitored the intertidal invertebrate community for fifteen months following a replenishment project at eight beaches, each with replenished and control sections, across San Diego County. Nearly all taxa showed major declines in abundance immediately following replenishment. Populations of talitrid amphipods and the bean clam Donax gouldii recovered within one year, sooner than in previous studies. On some beaches, populations of the mole crab Emerita analoga bloomed four months after replenishment and were more numerous on replenished portions of beaches at that time. Mole crab populations subsequently declined and no longer differed by treatment. The polychaete community, composed of Scolelepis sp. and several other numerically important taxa, showed a strong replenishment-induced reduction in abundance that persisted through the end of the study. The large negative effect of replenishment on polychaetes, coupled with their overall importance to the invertebrate community, resulted in a more than twofold reduction in overall invertebrate abundance on replenished beaches at 15 months. Such reductions may have far reaching consequences for sandy beach ecosystems, as community declines can reduce prey availability for shorebirds and fish. As this and other recent studies have revealed longer times for the recovery of intertidal invertebrates than previously observed, longer study periods and more cautious estimates regarding the magnitude, variability, and duration of impacts of beach replenishment for management decision-making are warranted.

Keywords: Beach replenishment, Beach nourishment, Impact assessment, Community recovery, Polychaetes, Intertidal invertebrates 


\section{Introduction}

Sandy beaches make up two-thirds of the Earth's shorelines, providing critical ecological,

27 commercial, and cultural resources for communities worldwide. As population growth and the

28 associated pressures of urbanization and climate change place further stress on sandy beaches,

29 the threat of degradation of these ecosystems increases (Brown \& McLachlan, 2002; Peterson \&

30 Bishop, 2005; Defeo et al., 2009). Because of their economic value, interest in preserving sandy

31 beach environments is growing, and a variety of practices to combat beach loss have been

32 implemented. Solutions range from constructing structures that maintain beach width, to

33 replenishment of beaches using offshore sand (McLachlan \& Brown, 2006). Beach

34 replenishment, the loading of sand on depleted beaches, is viewed as an ecologically conscious

35 solution to erosion because it lacks the potential long-term impacts of hard solutions such as sea

36 walls (Hanson et al., 2002; McLachlan \& Brown, 2006; Cooke et al., 2012). Nevertheless,

37 replenishment efforts often cite economic concerns such as coastal flooding risk or reduced

38 tourism as motivation for rebuilding beaches, while potential ecological consequences hold less

39 importance (Hanson et al., 2002; Lew \& Larson, 2005; Sandag \& U.S. Army Corps of 40 Engineers, 2011).

However, perturbations in the intertidal sandy beach community can have cascading

42 effects on higher trophic levels, reducing prey availability for shorebirds, juvenile fish, and a

43 host of other organisms (McLachlan \& Brown, 2006). Reductions in foraging rates of shorebirds

44 and fish have been shown to follow human-induced reductions in benthic invertebrate 45 abundance, ranging from simple trampling to replenishment (Dugan et al., 2003; Neuman et al., 46 2008; Peterson et al., 2006; Quammen, 1984; Wilber et al., 2003). Benthic invertebrates also 
47 play an important role in nutrient cycling, breaking down both marine and terrestrial organic

48 matter and providing coastal waters with the nutrient inputs essential for processes such as

49 phytoplankton growth (Schlacher et al., 2008; Defeo et al., 2009; Cisneros et al., 2011; Dugan et

50 al., 2011; Leewis et al., 2012). Accordingly, an ill-planned replenishment regime affecting

51 beaches with high rates of shorebird use and nutrient cycling could have far reaching ecosystem

52 consequences.

The limited number of published beach replenishment (also called nourishment) studies

54 show considerable variation in results (Table 1). Although certain taxa (e.g. haustoriid 55 amphipods, Emerita talpoida, Scolelepis squamata) are repeatedly investigated, no single study

56 has addressed the responses of all core intertidal taxa (Table 1). For most taxa, overall responses

57 to replenishment are uniform; amphipods, mole crabs (Emerita sp.), and bean clams (Donax sp.)

58 tend to respond negatively, while the polychaete Scolelepis squamata responds positively or is

59 unaffected by replenishment. Most of the differences between studies are found in the time it

60 took for organisms to recover; Schlacher et al. (2012) saw complete recovery of lower intertidal

61 haustoriid amphipods within five months, while Peterson et al. (2014) failed to see a return to

62 control levels after three years. Emerita talpoida, Donax sp., and Scolelepis squamata all show

63 variability among studies in time to recovery (Table 1). Another feature of previous studies is

64 that they sampled either a single beach (Schlacher et al., 2012), used a time series design 65 consisting of sampling different beaches replenished at various times in the past (Leewis et al., 66 2012), or employed designs in which sampled replenished and control beaches were spatially 67 segregated rather than interspersed (Peterson et al., 2006, 2014).

Southern California has a long history of implementing beach replenishment to combat 69 continual erosion (Willis \& Griggs, 2003). Sediment contributions from sea cliff erosion and 
70 river runoff naturally rebuild the region's beaches (Young \& Ashford, 2006) but controls on cliff

71 erosion, in conjunction with dams and jetties, now interrupt the input and flow of sediment in

72 coastal areas (Moore et al., 1999; Sherman et al., 2002; Willis \& Griggs, 2003). In light of these

73 changes and the potential economic cost of beach erosion, the county of San Diego has

74 implemented two recent replenishment projects. The first, which occurred in 2001, was largely

75 successful in expanding target beaches for several years post-replenishment, though no study of

76 its impact on invertebrates was performed, and provided impetus for an additional project in

772012 (Sandag \& U.S. Army Corps of Engineers, 2011). During the fall of 2012, eight beaches

78 across San Diego County were replenished with a total of 1.76 million cubic meters of sand as

79 part of the Regional Beach Sand Project II (RBSP II; Figure 1). Only portions of each beach

80 were replenished, leaving unreplenished control sections with the intent of leaving areas for

81 foraging birds and fish. Replenishment sediment was pulled from three offshore sites with fine-

82 medium sand, selected for best match to the grain size structure of recipient sites (Sandag \& U.S.

83 Army Corps of Engineers, 2011).

No previous examination of replenishment had the opportunity to examine its effects on

85 the total invertebrate community across so many beaches, with control and treatment regions of

86 each beach. Such a design facilitates the understanding the general affects of replenishment as

87 well as the heterogeneity of responses among beaches. This study examines the effects of the

882012 replenishment in San Diego in order to: 1) Quantify initial impacts and recovery rates of

89 each component of the sandy beach invertebrate community. 2) Quantify variability among

90 beaches both in the invertebrates present and in taxon-specfic responses to replenishment. 3)

91 Assess patterns of community diversity and structure following replenishment and the variability

92 of response to replenishment across replicate beaches within a region. 


\section{2. Methods}

95

96

97

\subsection{Study sites and sampling design}

Sampling was conducted at four time periods to account for both seasonality and time since disturbance: 1 (Fall 2012), 4 (Winter 2013), 12 (Fall 2013), and 15 (Winter 2014) months after replenishment. Days with the lowest low tides for that season were chosen for sampling, permitting transects to extend from the low low tide line to the upper limit of the intertidal. During each sample period, two replicate transects were surveyed in both the replenished and unreplenished sections, totaling four transects per site. $10 \mathrm{~cm}$-wide sample cores were taken at $20 \mathrm{~cm}$ depth and $5 \mathrm{~m}$ intervals along each transect. Sediment cores were sifted through a $1 \mathrm{~mm}$ sieve, and remaining organisms were transferred to $70 \%$ or $95 \% \mathrm{EtOH}$. Organisms were then identified to the lowest possible taxonomic rank using morphology.

\subsection{Taxon-specific abundances}

Transects varied in length due to differences in slope, producing unequal numbers of cores per transect. To account for this irregularity, as well as the patchy distribution of organisms in the intertidal, mean abundance of each taxon per core was calculated for each transect. Standard ANOVA was deemed problematic for testing the effects of replenishment on these values, due to the high number of zeroes, especially when analyzing particular taxonomic groups, causing extreme non-normality of the data (Shapiro's test, $\mathrm{p}<0.0001$ for all taxa; Underwood 1997).

Instead of using classical ANOVA, we ran a series of restricted permutation significance tests (Anderson \& Braak 2003). For permutations, transect values were sampled without replacement within each site, so as to break any existing associations between the explanatory 
116 factors and the mean abundance data. Linear full factorial mixed models were then constructed 117 treating replenishment status and time as fixed effects while beach and interactions with beach 118 were random effects. We treated time as a nominal variable with four states $(1,4,12$, and 15 119 months after replenishment) because it simplified the model relative to treating year and season 120 as separate factors. Inspection allowed assessment of whether time effects were due to 121 seasonality, monotonic changes in abundance through time, or transient surges in abundance. A 122 modified version of the PERMANOVA utility available in the R package vegan (Okansen et al., 123 2015) was used to rapidly permute the data. After each permutation, an F-statistic for each effect 124 was calculated and the process was repeated 5000 times, allowing construction of a null 125 distribution of F-statistics. F-statistics were calculated as appropriate for mixed models with 126 balanced designs. Mean squares for fixed effects were tested over mean squares for interactions 127 between that effect and the random effect beach. The effect of beach was tested over the 128 composite mean square made up of the sum of the mean squares for the two two-way 129 interactions involving the beach effect minus the mean square of the three-way interaction (Zar 1999). P-values were calculated from the proportion of permuted F-statistics greater than or 131 equal to the observed values. This process was implemented to analyze mean abundance for the 132 four most abundant taxa (Table 2) separately: Emerita analoga, talitrid amphipods, Scolelepis 133 sp., Donax sp., and for three groups of taxa: all polychaetes (including Scolelepis sp.), all 134 invertebrates, and all invertebrates except Emerita analoga (see below).

\section{$135 \quad 2.3$ Community composition and recovery}

In order to understand the effects of replenishment on community diversity, taxon

137 richness was calculated for each transect. The mixed-model restricted permutation analysis 138 described above was implemented analyzing richness values in place of abundance. 
To visualize changes in community composition through time, non-metric

140

141

142

143

144

145

146

147

148

149

150

151

152

153

154

155

156

157

158

159

160

161

multidimensional scaling (NMDS) was performed on the per-transect abundance data from the

entire study as well as individual sampling periods, using the ordination tools available in the $\mathrm{R}$ package vegan for community ecology (Okansen et al., 2015). The data were log-transformed to reduce the weight of extremely abundant species (Anderson et al., 2011). A brief scan of the dataset revealed a high number of zeroes for abundance values, especially in the first month after disturbance. Zero-heavy datasets present challenges for many distance measures used in ordination. However, these zeroes might be informative, given that the common absence of an organism from samples could indicate an effect of disturbance. To include joint-absences in the ordination, a Euclidean dissimilarity matrix was constructed from the log-transformed community data (Anderson et al., 2011). Use of an adjusted Bray Curtis measure resulted in stress values greater than 0.20 , indicating that the dissimilarity measure was not appropriate for ordination. To accompany each NMDS, PERMANOVAs were run on identical datasets to test the influence of replenishment, site, and their interaction on community structure using the same mixed model approach described above.

\section{Results}

\subsection{Species surveyed and beach effects}

For most specimens, taxonomy was resolved to genus or species level. Given our expertise, this was not possible for certain groups, such as Nemertea (ribbon worms) or amphipods of the family Talitridae (sand fleas) that are difficult to identify morphologically. A total of 20 different species or groups were recorded during the study (Table 2). Taxon abundances were highly variable, with the mole crab Emerita analoga accounting for $29 \%$ of all 
162 collected organisms although its abundance varied greatly among beaches with $69.7 \%$ of all 163 individuals coming from just two of the eight beaches. Only two individuals of the usually 164 common pismo clam (Tivela sp.) were collected during the entire study (Dugan \& Hubbard, 165 2000; Table 2). Several polychaetes were identified with no single species exceeding $12.7 \%$ of 166 total invertebrate abundance. As a group, however, polychaetes accounted for $37.6 \%$ of all 167 organisms sampled (Table 1).

High variability in abundance was observed across sediment cores, transects, and

169 beaches. Only 12 taxa were sampled from all eight beaches. Even relatively abundant talitrid 170 amphipods (16.2\% of individuals) and the polychaete Thoracophelia sp. (5.4\% of individuals)

171 were completely absent from samples from certain beaches.

\section{$172 \quad 3.2$ Effects on abundance}

Replenishment affected the taxa studied in different ways and over different time periods.

174 All invertebrate groups showed reduced densities on replenished sites 1 month after 175 replenishment (Fig. 2) except Emerita analoga which was rare on both treatment and control 176 sites at this time. Throughout the study polychaete density was reduced by replenishment and 177 remained at approximately one third of control levels after fifteen months (Fig. 2; Table 3, 178 treatment effect, $\mathrm{P}<0.01$ ). Density of polychaetes also tended to increase through time (Fig. 1;

179 Table 3, time effect, $\mathrm{P}<0.01$ ). For all polychaetes taken together, there was also a significant 180 three-way interaction (Table $3, \mathrm{P}<0.01$ ), reflecting variation in the magnitude of the effect of 181 replenishment across time and beaches (Fig. 4a). In general, on beaches with substantial densities 182 of polychaetes at control sites, lower densities were found on replenished portions of these same 183 beaches. On beaches with low densities of polychaetes on control sites, differences between 
184 control and replenished portions were small or reversed, at least for some time periods (e.g. 185 North and South Carlsbad, Fig. 3a).

Not surprisingly, Scolelepis sp., which accounted for $27.5 \%$ of all polychaetes, followed 187 the same trend (Fig. 2) but the main effect of replenishment was not statistically significant 188 because of variation among beaches in the effects of replenishment (Table 3 , site*treatment 189 interaction, $\mathrm{P}<0.05)$. As with all polycheates analyzed together, on beaches with the highest 190 abundance of Scolelepis (Solana Beach, Imperial Beach, Table 2) there was a substantial density 191 reduction at replenished portions while on beaches with relatively low Scolelepis sp. densities, 192 differences between control and replenished sites were small and sometimes reversed. Emerita analoga underwent a population boom at four months after replenishment (Fig.

194 2), with specimens from this period accounting for $89 \%$ of all mole crabs, and $25.1 \%$ of all 195 invertebrates collected throughout the study. This temporary flush accounts for the effect of time 196 (Table $3, \mathrm{P}<0.001$ ) on this taxon. This population boom was only observed at some beaches 197 (Fig. 3b; Table 3, site*time interaction $\mathrm{P}<0.001$ ). At this time, and on these beaches, the 198 densities of mole crabs at replenished sites surpassed those found at control sites (Fig. 3b; Table 1992 , three-way interaction, $\mathrm{P}<0.01)$. After 4 months, densities of Emerita analoga declined and no 200 further differences were seen between control and replenished portions for the remainder of the 201 study (Figs. 2, 3b).

Densities of the bean clam Donax gouldii fluctuated across census periods (Fig. 2; Table 2033 , effect of time, $\mathrm{P}<0.01$ ). Initially, replenishment tended to reduce the density of this clam but 204 when its populations peaked 12 months after replenishment, density tended to be higher on 205 replenished than control sites, though not significantly so (Fig. 2). This temporary trend of higher 
Donax density on replenished sites was restricted to beaches where Donax reached substantial population densities (Table 3, three-way interaction, $\mathrm{P}<0.01$ ).

For talitrid amphipods, populations tended to increase through time (Fig. 2; Table 3, effect of time, $\mathrm{P}<0.05)$. On beaches where amphipods reached high density at some time during the study (e.g. Cardiff and Moonlight, Table 1), replenishment tended to negatively influence density while at beaches with lower amphipod densities, this trend was small or reversed (Table 2, three-way interaction, $\mathrm{P}<0.001)$.

If Emerita analoga, which was both transiently very abundant and positively affected by replenishment on beaches where populations bloomed, is removed from the analysis, the density of all other invertebrates grouped together was negatively affected by replenishment (Fig. 2; Table 3, treatment effect, $\mathrm{P}<0.05$ ), was higher in the second year of the study (Fig. 2; Table 3, time effect, $\mathrm{P}<0.001$ ), and was affected in complicated ways by interactions between treatment, time, and site due to the combination of taxon-specific effects detailed earlier (Fig. 1; Table 3).

Due largely to the population flush and transient effects of replenishment on Emerita analoga, replenishment had no significant effect on overall invertebrate abundance (Table 3) although total invertebrate density on replenished transects averaged $48 \%$ that of control transects after 15 months (Fig. 2). The treatment by time interaction reflects primarily the increased abundance of invertebrates on replenished portions of beaches at 4 months, due to the flush of Emerita analoga, while reduced invertebrate densities on replenished sites were seen at all other time periods (Fig. 2). The treatment by site interaction reflects differences in the average effect of replenishment between beaches that exhibited high densities of Emerita analoga at four months and those that did not. Interactions involving time since disturbance also reflect transient, beach-specific, mole crab densities (Fig. 3). 


\subsection{Effects on Diversity}

Replenishment reduced taxon richness (Table 4, Fig. 4). The effect was strong at 1 month, where control sites had, on average, three-fold more taxa than replenished sites. By 15 months post-disturbance, effects of replenishment on this diversity measure had disappeared. The significant effect of time on diversity is largely due to seasonality, with higher diversity during fall than winter census periods. The strong treatment by time interaction reflects the diminished effect of replenishment over the course of study.

\subsection{Community structure and recovery}

Non-metric multidimensional scaling (NMDS) of the log-transformed community data across all time periods using a Euclidean distance measure showed clustering of the four most abundant polychaetes (Scolelepis sp., Nephtys californiensis, Thoracophelia sp., unknowns), indicating similarities in distribution and abundance across time and replenishment (Figure 5). Three less common polychaetes, Naineris dendritica, Orbinia johnsoni, and Hemipodia borealis, did not group with any other polychaete taxa. Separation of Emerita analoga, Donax gouldii, and talitrid amphipods suggest divergent patterns of abundance across time and treatment. A PERMANOVA revealed significant effects of replenishment $(\mathrm{P}=0.004)$ and time since disturbance $(\mathrm{P}=0.001)$ on community structure, as well as a strong interaction effect $(\mathrm{P}=0.013)$.

This replenishment-by-time interaction is elucidated when NMDS and PERMANOVA analysis are applied to each time period (Figure 6). One month after replenishment transects were distinctly clustered by treatment $(\mathrm{P}=0.001)$, with transects from replenished beaches being nearly identical to each other, and control transects showing considerable variability. However, no overall replenishment effect was observed for the remaining time periods. Rather, a strong replenishment-by-beach interaction persisted from four months on, indicating variability in the effect of replenishment across beach communities. Even at the end of the study, invertebrate 
253 communities at some beaches were still strongly affected by replenishment $(\mathrm{P}=0.009)$. The

254 NMDS plot at 15 monthse showed clear separation of transects at Imperial Beach (IB), 255 Moonlight (Moon), Cardiff (Car), and South Carlsbad (SC) according to replenishment status 256 indicating fundamental differences in the invertebrate communities — while no pattern was 257 evident in the remaining four beaches.

258

259

260

261

262

263

264

265

266

267

268

269

270

271

272

273

274

275

\section{Discussion}

We found substantial effects of beach replenishment on sand-dwelling invertebrates such that replenished sections of beaches, on average, had only $48 \%$ as many invertebrates as controls after 15 months (Fig. 2). Beach replenishment had major impacts on community composition as well, initially lowering standard metrics of diversity, and affecting the structure of communities on some beaches through to the end of the study (Figure 5). A salient feature of this study's design was the assessment of variation across beaches in the effects of replenishment. Strong two and three way interactions involving site were found for all taxa or groups examined, and in community-wide analyses. This variation among beaches within a region may help explain variation among studies in the effects of replenishment summarized in Table 1 and caution against broad generalizations about the magnitude and duration of replenishment effects, even within a region. Nevertheless, the observed overall effects of replenishment on invertebrate abundance may have implications up the food chain for birds and fish known to feed on them.

The effects of replenishment on invertebrate abundance were primarily driven by the responses of polychaetes and the mole crab Emerita analoga. The response displayed by $E$. analoga — blooming at four months and becoming more common in replenished sites — had a major impact on total invertebrate densities, offsetting the decline in polychaetes such that no 
276 overall effect of replenishment on total abundance of invertebrates was detected. After the $E$. 277 analoga bloom subsided, polychaetes were the numerically dominant component of the 278 community, and exhibited reduced densities on replenished portions of beaches throughout the 279 study.

These results regarding Emerita analoga and polychaetes conflict with the findings of 281 previous studies, which reported pronounced negative effects of replenishment on Emerita 282 talpoida (Hayden \& Dolan, 1974; Peterson et al., 2000a, 2006, 2014; Leewis et al., 2012; 283 Manning et al., 2014) and positive or neutral effects on Scolelepis sp. and/or polychaetes in 284 general (Menn et al., 2003; Peterson et al, 2006, 2014; Leewis et al., 2012; Manning et al., 2014;

285 but see Schlacher and Thompson, 2012). The response of E. analoga may be explained in part by 286 processes other than replenishment that produce boom-bust cycles. The long pelagic duration (32876 months) of E. analoga larvae make it possible for beach populations to be sustained by long 288 distance recruits (Efford, 1969; Dugan et al., 1991; Dugan \& Hubbard, 1996; Dawson et al., 289 2011). Coastal currents may affect the spread of larvae and produce sudden, site-specific, 290 population blooms (Dugan \& Hubbard, 1996; Sorte et al., 2001; Diehl et al., 2007). The 291 observed bloom of E. analoga at four months may have resulted from a significant recruitment 292 event on certain beaches driven by changes in local ocean conditions, followed by mortality and 293 population decline. What is less clear is why mole crabs were more abundant on replenished 294 sites. Burrowing experiments show E. analoga to be a substrate generalist outside of very fine295 textured sediment (Dugan et al., 2000; Viola et al., 2013) and previous studies have shown no 296 correlation with environmental variables such as sediment structure and beach slope (Dugan \& 297 Hubbard, 1996). It is possible that replenishment changed swash zone characteristics which are 298 known to affect settlement of E. analoga and other crustaceans (Cubit, 1969; Dugan et al., 1991, 
1994, 2000; McLachlan, 1996; McLachlan \& Brown, 2006; Speybroeck et al., 2006; Defeo \& McLachlan, 2011). Another possibility is that recently replenished portions of beaches may have been less compacted than control sections facilitating burrowing and increasing residence times of mole crabs such that they were aggregated on replenished sites.

Previous studies of the effects of replenishment on polychaetes (Menn et al., 2003; Leewis et al., 2012; Manning et al., 2014; Peterson et al., 2006, 2014) often focused on a single species, Scolelepis squamata. None reported long-term negative effects and in some cases replenishment had a positive effect on the polychaete(s) studied (Menn et al., 2003; Leewis et al., 2012; Manning et al., 2014). In our study, Thoracophelia sp., Nephtys californiensis, Hemipodia simplex, Naineris dendritica, Orbinia johnsoni, and unknown polychaetes accounted for a large proportion (24\%) of all collected invertebrates, were found in approximately equal numbers, and in aggregate were twice as abundant as Scolelepis sp. While analyzing Scolelepis sp. alone returned no significant effect of replenishment, mean densities were consistently lower in replenished than control sites (Fig. 2) while as a community (including Scolelepis sp.), polychaetes showed reduced numbers on replenished sites through the end of the study. Reasons for the conflict between our findings and previous studies are unknown. Sand churned up from offshore and thickly deposited on beaches is likely to be devoid of intertidal polychaetes and may have caused mortality of buried ones. Subsequent population growth will most likely occur via recruitment by planktonic larvae, due to the limited mobility of sandy beach polychaetes (Rouse \& Pleijel, 2001). But in contrast to E. analoga, short times in the plankton (1-2 months for T. mucronata and S. squamata; Dales, 1952; Speybroeck et al., 2007) and long times until reproduction (2 years for S. squamata; Speybroeck et al., 2007) could delay recovery of denuded polychaete populations following replenishment. Interactions between regional variation in life 
322 history (Speybroeck et al. 2007), recruitment, morphology (Williams, 2007; Rocha \& Paiva, 323 2012) and beach and fill characteristics may explain divergent results between ours and previous 324 replenishment studies.

325 One of the more striking results in this study was how strongly beach-specific 326 idiosyncrasies influenced invertebrate abundance. Many beaches exhibited extreme asymmetry 327 in community structure, often with one group dominating the intertidal macrofauna (Table 2). 328 For instance, tailitrid amphipods were 36 times more abundant than the second most common 329 group at North Carlsbad. In contrast, Batiquitos hosted a more evenly distributed, low-density 330 intertidal community with similar numbers of mole crabs, amphipods, and polychaetes. All taxa examined were affected to some degree by significant interactions between sites and other 332 factors. At half of the beaches, densities of E. analoga were near zero for the entire study, while 333 beaches that accumulated appreciable numbers of mole crabs uniformly displayed increased 334 densities on replenished sites. Polychaete responses were similarly variable. On beaches where 335 polychaete populations increased substantially through the course of the study, population 336 densities were higher on control portions (Fig 3). On beaches where polychaete densities were 337 lowest at the end of the study, differences between replenished and control sites were small or 338 reversed. Observed interactions between site and treatment effects in whole-community analyses 339 were largely driven by these site-specific effects on E. analoga and polychaetes. Variability is 340 characteristic of sandy beach communities (Dugan et al., 2000; Defeo \& McLachlan, 2005; 341 Schlacher et al., 2008) and complicates our ability to generalize replenishment affects. The 342 necessity of examining multiple beaches to document the range of replenishment effects is clear. Reduction of average beach invertebrate densities by half, as observed here through 15 344 months, could seriously disrupt the sandy beach food web. Southern California beaches are host 
345 to more than twenty five species of shorebirds that forage for benthic invertebrates (Dugan et al.,

346

347

348

349

350

351

352

353

354

355

356

357

358

359

360

361

362

363

364

365

366

367

2000, 2003; Hubbard \& Dugan, 2003). Common prey items include Emerita analoga, talitrid amphipods, isopods, and polychaetes (Stenzel et al., 1976; Quammen, 1984; Hubbard \& Dugan, 2003; Neuman et al., 2008). Reductions in invertebrate abundance can cause decreased habitat use by shorebirds and fish (Peterson et al., 2006; Peterson et al., 2014; Quammen, 1984; Dugan et al., 2003; Speybroeck et al., 2006; Wilber et al,. 2003; Peterson et al., 2000b; Dolbeth et al., 2008). Therefore, the observed decline in invertebrate abundance could negatively impact shorebird and fish feeding for at least fifteen months after replenishment. The timing of replenishment may exacerbate effects on shorebirds. Migrating species in Southern California account for a large increase in shorebird numbers during the winter and spring, putting extra pressure on invertebrate populations during these times (Hubbard \& Dugan, 2003). Although the E. analoga bloom in winter 2013 likely favored foraging shorebirds, a winter decline-like that seen at 15 months - might put greater stress on shorebird populations than a similar effect in summer. This is especially relevant for areas like San Diego, where degradation of already limited mudflats force shorebirds to rely heavily on sandy beaches (Page et al., 1999; Hubbard \& Dugan, 2003).

The environmental impact statement for this replenishment project (RBSP II) anticipated a complete recovery of the intertidal invertebrate community within one year of sand deposition (SANDAG \& U.S. Army Corps of Engineers, 2011). Full recovery will clearly take longer. Because more recent studies show longer recovery times (this study; Peterson et al., 2014; Manning et al., 2014), longer estimates regarding the extent of replenishment's effects are warranted. Keeping in mind that our results for some taxa conflict with those of previous studies, further studies of replenishment affects are warranted in order to understand this variation. With 
more data, longer studies, and greater attention to which physical features of beaches account for variation in replenishment effects, we may gain a deeper understanding of how replenishment impacts beach invertebrates. Our well-replicated study of the entire invertebrate community points to the need to understand and account for among-beach variation both as a research goal and management necessity.

\section{Acknowledgements}

We thank Greg Rouse for help in identifying specimens. Molly Bun, Carrilyn Cameron, Amanda Chisholm, Megan Flaherty, Sara Kramer, Drew Madden, Tracy Park, Hannah Scholes, Jackie Sikkema, and James Whalen helped in collecting data. Tyler Wooldridge was partially supported by a grant from the Agouron Foundation. This work was also partially supported by NSF TUES 1140640 to HJH and JRK.

\section{References}

Anderson, M., Braak, C. Ter, 2003. Permutation tests for multi-factorial analysis of variance. J. Stat. Comput. Simul. 73, 85-113.

Anderson, M.J., Crist ,T.O., Chase, J.M., Vellend, M., Inouye, B.D., Freeston, A.L., Sanders, N.J., Cornell, H.V., Comita, L.S., Davies, K.F., Harrison, S.P., Kraft, N.J.B., Stegen, J.C., Swenson, N.G., 2011. Navigating the multiple meanings of $\beta$ diversity: a roadmap for the practicing ecologist. Ecol. Lett. 14, 19-28.

Brown, A., McLachlan, A., 2002. Sandy shore ecosystems and the threats facing them: some predictions for the year 2025. Environ. Conserv. 29 (1), 62-77.

Cisneros, K.O., Smit, A.J., Laudien, J., Schoeman, D.S., 2011. Complex, dynamic combination of physical, chemical and nutritional variables controls spatio-temporal variation of sandy beach community structure. PLoS One 6, 23-27.

Cooke, B.C., Jones, A.R., Goodwin, I.D., Bishop, M.J., 2012. Nourishment practices on Australian sandy beaches: A review. J. Environ. Manage. 113, 319-327.

Cubit, J., 1969. Behavior and physical factors causing migration and aggregation of the sand crab Emerita analoga (Stimpson). Ecology 50, 118-123.

Dales, R.P., 1952. The larval development and ecology of Thoracophelia mucronata (Treadwell). Biol. Bull. 102, $232-242$. 
Dawson, M.N., Barber, P.H., González-Guzmán, L.I., Toonen, R.J., Dugan, J.E., Grosberg, R.K. (2011) Phylogeography of Emerita analoga (Crustacea, Decapoda, Hippidae), an eastern Pacific Ocean sand crab with long-lived pelagic larvae. J. Biogeogr. 38, 1600-1612.

Defeo, O., McLachlan, A., 2005. Patterns, processes and regulatory mechanisms in sandy beach macrofauna: a multi-scale analysis. 295, 1-20.

Defeo, O., McLachlan, A., 2011. Coupling between macrofauna community structure and beach type: A deconstructive meta-analysis. Mar. Ecol. Prog. Ser. 433, 29-41.

Defeo, O., McLachlan, A., Schoeman, D.S., Schlacher, T.A., Dugan, J., Jones, A., Lastra, M., Scapini, F., 2009. Threats to sandy beach ecosystems: A review. Estuar. Coast. Shelf. Sci. 81, 1-12.

Diehl, J.M., Toonen, R.J., Botsford, L.W., 2007. Spatial variability of recruitment in the sand crab Emerita analoga throughout California in relation to wind-driven currents. Mar. Ecol. Prog. Ser. 350, 1-17.

Dolbeth, M., Martinho, F., Leitão, R., Cabral, H., Pardal, M.A., 2008. Feeding patterns of the dominant benthic and demersal fish community in a temperate estuary. J. Fish. Biol. 72, 2500-2517.

Dugan, J.E., Hubbard, D.M., 1996. Local variation in populations of the sand crab Emerita analoga on sandy beaches in southern California. Rev. Chil. Hist. Nat. 69, 579-588.

Dugan, J.E., Hubbard, D.M., Lastra, M., 2000. Burrowing abilities and swash behavior of three crabs, Emerita analoga Stimpson, Blepharipoda occidentalis Randall, and Lepidopa californica Efford (Anomura, Hippoidea), of exposed sandy beaches. J. Exp. Mar. Bio. Ecol. 255, 229-245.

Dugan, J.E., Hubbard, D.M., Martin, D.L., Engle, J.M., Richards, D.M., Davis, G.E., Lafferty, K.D., Ambrose, R.F., 2000. Macrofauna communities of exposed sandy beaches on the southern California mainland and Channel Islands. Fifth Calif. Islands. Symp. Miner. Manag. Serv. OCS Study, MMS 99-0038, 339-346.

Dugan, J.E., Hubbard, D.M., McCrary, M.D., Pierson, M.O., 2003. The response of macrofauna communities and shorebirds to macrophyte wrack subsidies on exposed sandy beaches of southern California. Estuar. Coast. Shelf Sci. 58, 25-40.

Dugan, J.E., Hubbard, D.M., Page, H.M., Schimel, J.P., 2011. Marine macrophyte wrack inputs and dissolved nutrients in beach sands. Estuaries and Coasts 34, 839-850.

Dugan, J.E., Hubbard, D.M., Wenner, A.M. (1994) Geographic variation in life-history of the sand crab, EmeritaAnaloga (Stimpson) on the California coast: Relationships to environmental variables. J. Exp. Mar. Bio. Ecol. $181,255-278$.

Dugan. J.E., Wenner, A.M., Hubbard, D.M., 1991. Geographic variation in the reproductive biology of the sand crab Emerita analoga (Stimpson) on the California coast. J. Exp. Mar. Bio. Ecol. 150, 63-81.

Efford, I.E., 1970. Recruitment to sedentary marine populations as exemplified by the sand crab, Emerita analoga (Decapoda, Hippidae). Crustaceana 18 (3), 293-308.

Fanini, L., Marchetti, G.M., Scapini, F., Defeo, O., 2000, Effects of beach nourishment and groynes building on population and community descriptors of mobile arthropodofauna. Ecol. Indic. 9, 167-178.

Gorzelany, J.F., Nelson, W.G., 1987. The effects of beach replenishment on the benthos of a sub-tropical Florida beach. Mar. Env. Res. 21, 75-94. 
Hanson, H., Brampton, A., Capobianco, M., Dette, H.H., Hamm, L., Laustrup, C. Lechuga, A., Spanhoff, R., 2002. Beach nourishment projects, practices, and objectives - a European overview. Coast. Eng. 47, 81-111.

Hayden, B., Dolan, R., 1974. Impact of beach nourishment on distribution of Emerita talpoida, the common mole crab. J. Waterw. Harb. Coast. Engineeering Div. 100, 123-132.

Hubbard, D.M., Dugan, J.E., 2003. Shorebird use of an exposed sandy beach in southern California. Estuar. Coast. Shelf Sci. 58, 41-54.

Jones, A.R., Murray, A., Lasiak, T a., Marsh RE (2008) The effects of beach nourishment on the sandy-beach amphipod Exoediceros fossor: Impact and recovery in Botany Bay, New South Wales, Australia. Mar. Ecol. $29,28-36$.

Leewis, L., van Bodegom, P.M., Rozema, J., Janssen, G.M., 2012. Does beach nourishment have long-term effects on intertidal macroinvertebrate species abundance? Estuar. Coast. Shelf Sci. 113, 172-181.

Lew, D.K., Larson, D.M., 2005. Valuing recreation and amenities at San Diego County beaches. Coast. Manag. 33, $71-86$.

Manning, L., Peterson, C., Bishop, M. 2014. Dominant macrobenthic populations experience sustained impacts from annual disposal of fine sediments on sandy beaches. Mar. Ecol. Prog. Ser. 508, 1-15.

Mattos, G., Cardoso, R.S., Dos Santos, A.S., 2013. Environmental effects on the structure of polychaete feeding guilds on the beaches of Sepetiba Bay, south-eastern Brazil. J. Mar. Biol. Assoc. United Kingdom 93, 973980 .

McLachlan, A., 1996. Physical factors in benthic ecology: Effects of changing sand particle size on beach fauna. Mar. Ecol. Prog. Ser. 131, 205-217.

McLachlan, A., Brown, A., 2006. The Ecology of Sandy Shores, 2nd edn. Academic Press, Amsterdam, 392 pp.

Menn, I., Junghans, C., Reise, K., 2003. Buried alive: Effects of beach nourishment on the infauna of an erosive shore in the North Sea. Senckenbergiana maritima 32, 125-145.

Moore, L.J., Benumof, B.T., Griggs, G.B., 1999. Coastal erosion hazards in Santa Cruz and San Diego counties, California. J. Coast. Res. S28, 121-139.

Murphy, E.A., Dorgan, K.M., 2011. Burrow extension with a proboscis: mechanics of burrowing by the glycerid Hemipodus simplex. J. Exp. Biol. 214, 1017-1027.

Neuman, K.K., Henkel, L.A., Page, G.W., 2008. Shorebird use of sandy beaches in central California. Waterbirds $31,115-121$.

Okansen, J., Blanchet, F.G., Kindt, R., Legendre, P., Minchin, P.R., O'Hara, R.B., Simpson, G.L., Solymos, P., Stevens, H.H., Wagner, H., 2015. Vegan: Community Ecology Package. R package version 2.21. http://CRAN.R-project.org/package=vegan

Page, G.W., Stenzel, L.E., Kjelmyr, J.E., Kjelmyr, J.E., 1999. Overview of shorebird abundance and distribution in wetlands of the Pacific coast of the continuous United States. Condor 101, 461-471.

Peterson, C.H., Bishop, M.J., 2005. Assessing the environmental impacts of beach nourishment. Bioscience 55, 887896. 
471

472

473

474

475

476

477

478

479

480

481

482

483

484

485

486

487

488

489

490

491

492

493

494

495

496

497

498

499

500

501

502

503

504

505

506

507

Peterson, C.H., Bishop, M.J., D’Anna, L.M., Johnson, G.A., 2014. Multi-year persistence of beach habitat degradation from nourishment using coarse shelly sediments. Sci. Total Environ. 487, 481-492.

Peterson, C.H., Bishop, M.J., Johnson, G.A., D’Anna, L.M., Manning, L.M., 2006. Exploiting beach filling as an unaffordable experiment: Benthic intertidal impacts propagating upwards to shorebirds. J. Exp. Mar. Bio. Ecol. 338, 205-221.

Peterson, C.H., Hickerson, D.H.M., Johnson, G.G., 2000a. Short-term consequences of nourishment and bulldozing on the dominant large invertebrates of a sandy beach. J. Coast. Res. 16, 368-378.

Peterson, C.H., Summerson,H.C., Thomson, E., Lenihan, H.S., Grabowski, J., Manning, L., Micheli, F., Johnson, G., 2000b. Synthesis of linkages betweenn benthic and fish comunities as a key to protecting essential fish habitat. Bull. Mar. Sci. 66, 59-774.

Quammen, M.L., 1984. Predation by shorebirds, fish, and crabs on invertebrates in intertidal mudflats: An experimental test. Ecol. Soc. Am. 65, 529-537.

Rocha, M.B., De Paiva, P.C., 2012. Scolelepis (Polychaeta : Spionidae) from the Brazilian coast with a diagnosis of the genus. Zoologia 29, 385-393.

Rouse G, Pleijel F (2001) Polychaetes, 1st edn. Oxford, New York, 354 pp.

Sandag, U.S. Army Corps of Engineers, 2011. Environmental Assessment / Final Environmental Impact Report For the San Diego Regional Beach Sand Project II.

Schlacher, T.A., Noriega, R., Jones, A., Dye, T., 2012. The effects of beach nourishment on benthic invertebrates in eastern Australia: Impacts and variable recovery. Sci. Total Environ. 435-436, 411-417.

Schlacher, T.A., Schoeman, D.S., Dugan, J., Lastra, M., Jones, A., Scapini, F., McLachlan, A., 2008. Sandy beach ecosystems: Key features, sampling issues, management challenges and climate change impacts. Mar. Ecol. 29, 70-90.

Schlacher, T.A., Thompson, L., 2012. Beach recreation impacts benthic invertebrates on ocean-exposed sandy shores. Biol. Conserv. 147, 123-132.

Sherman, D., Barron, K., Ellis, J., 2002. Retention of beach sands by dams and debris basins in southern California. J. Coast. Res. 36, 662-674.

Sorte, C.J., Peterson, W.T., Morgan, C.A., Emmett, R.L., 2001. Larval dynamics of the sand crab, Emerita analoga, off the central Oregon coast during a strong El Niño period. J. Plank. Res. 23, 939-944.

Speybroeck, J., Alsteens, L., Vincx, M., Degraer, S., 2007. Understanding the life of a sandy beach polychaete of functional importance - Scolelepis squamata (Polychaeta: Spionidae) on Belgian sandy beaches (northeastern Atlantic, North Sea). Estuar. Coast. Shelf Sci. 74, 109-118.

Speybroeck, J., Bonte, D. Courtens, W., Gheskiere, T., Grootaert, P., Maelfait, J.-P., Mathys, M., Provoost, S., Sabbe, K., Stienen, E.W.M., Van Lancker, V., Vincx, M., Degraer, S., 2006. Beach nourishment: an ecologically sound coastal defence alternative? A review. Aquat. Conserv. Mar. Freshw. Ecosyst. 16, 419435.

Stenzel, L.E., Huber, H.R., Page, G.W., 1976. Feeding behavior and diet of the long-billed curlew and willet. Wilson Bull. 88, 314-332. 


\section{6}

Underwood, A.J., 1997. Experiments in ecology: Their logical design and interpretation using analysis of variance, 1st edn. Cambridge University Press, Cambridge, 509 pp.

Van Tomme, J., Vanden Eede, S., Speybroeck, J., Degraer, S., Vincx, M., 2013. Macrofaunal sediment selectivity considerations for beach nourishment programmes. Mar. Environ. Res. 84, 10-16.

Viola, S.M., Hubbard, D.M., Dugan, J.E., Schooler, N.K., 2013. Burrowing inhibition by fine textured beach fill: Implications for recovery of beach ecosystems. Estuar. Coast. Shelf Sci. 150, 142-148.

Wilber, D., Clarke, D., Ray, G., Burlas, M., 2003. Response of surf zone fish to beach nourishment operations on the northern coast of New Jersey, USA. Mar. Ecol. Prog. Ser. 250, 231-246.

Williams, J.D., 2007. New records and description of four new species of spionids (Annelida: Polychaeta: Spionidae) from the Philippines: the genera Dispio, Malacoceros, Polydora, and Scolelepis, with notes on palp ciliation patterns of the genus of Scolelepis. Zootaxa 1459, 1-35.

Willis, C.M., Griggs, G.B., 2003. Reductions in fluvial sediment discharge by coastal dams in California and implications for beach sustainability. J. Geol. 111, 167-182.

Young, A.P., Ashford, S.A. 2006. Application of airborne LIDAR for seacliff volumetric change and beachsediment budget contributions. J. Coast. Res. 22, 307-318.

Zar, J.H., 1999. Biostatistical Analsyis (4 ${ }^{\text {th }}$ edn). Prentice Hall, Lebanon Indiana, 663 pp. 


\section{Table 1}

Summary of findings from peer-reviewed beach replenishment studies. Initial response (R) and time until replenishment effects are no longer observed (T) are listed for intertidal taxa when available. A “-" indicates reduced abundance, a "+" indicates increased abundance, and "=" indicates no significant difference. A " $>$ " indicates that replenishment effects were still observable at the end of the study.

\begin{tabular}{|c|c|c|c|c|c|c|c|c|c|c|c|c|}
\hline & & mphipods & & Isopods & & nerita spp. & & onax spp. & & $\begin{array}{l}\text { Scolelepis } \\
\text { squamta }\end{array}$ & & $\begin{array}{c}\text { Other } \\
\text { olychaetes }\end{array}$ \\
\hline Citation & $\mathrm{R}$ & $\mathrm{T}$ & $\mathrm{R}$ & $\mathrm{T}$ & $\mathrm{R}$ & $\mathrm{T}$ & $\mathrm{R}$ & $\mathrm{T}$ & $\mathrm{R}$ & $\mathrm{T}$ & $\mathrm{R}$ & $\mathrm{T}$ \\
\hline $\begin{array}{l}\text { Fanini et al. } \\
2009\end{array}$ & $=$ & N/A & & & & & & & & & & \\
\hline $\begin{array}{l}\text { Gorzelany \& } \\
\text { Nelson } 1987\end{array}$ & & & & & & & $=$ & N/A & & & & \\
\hline $\begin{array}{l}\text { Hayden } \\
\text { \& Dolan } 1974\end{array}$ & & & & & - & 2 weeks & & & & & & \\
\hline $\begin{array}{l}\text { Leewis et al. } \\
2012\end{array}$ & - & 1 year & & & - & 1 year & - & 1 year & + & 1 year & & \\
\hline $\begin{array}{l}\text { Jones et al. } \\
2008\end{array}$ & - & 1 year & & & & & & & & & & \\
\hline $\begin{array}{l}\text { Manning et al. } \\
2014\end{array}$ & $=,-$ & $>1$ year & & & $=,-$ & $>1$ year & $=,-$ & $>1$ year & $=,+$ & 8 months & & \\
\hline $\begin{array}{l}\text { Menn et al. } \\
2003\end{array}$ & $=$ & N/A & & & & & & & + & $>4$ months & + & $>4$ months \\
\hline $\begin{array}{l}\text { Peterson et al. } \\
2000 \mathrm{a}\end{array}$ & & & & & - & $>10$ weeks & - & $>10$ weeks & & & & \\
\hline $\begin{array}{l}\text { Peterson et al. } \\
2006\end{array}$ & - & $>9$ months & & & - & $4-5$ months & - & $>9$ months & $=$ & N/A & $=$ & $\mathrm{N} / \mathrm{A}$ \\
\hline $\begin{array}{l}\text { Peterson et al. } \\
2014\end{array}$ & - & $>3$ years & & & - & 1 year & - & $>3$ years & $=$ & N/A & $=$ & N/A \\
\hline $\begin{array}{l}\text { Schlacher et al. } \\
2012\end{array}$ & - & 5 months & - & $>5$ months & & & & & & & - & 5 months \\
\hline
\end{tabular}


Table 2

Counts of all taxa collected during the study, organized by sample beach.

\begin{tabular}{|c|c|c|c|c|c|c|c|c|c|c|}
\hline Organism & Batiquitos & Cardiff & $\begin{array}{l}\text { Imperial } \\
\text { Beach }\end{array}$ & Moonlight & $\begin{array}{l}\text { North } \\
\text { Carlsbad }\end{array}$ & Oceanside & $\begin{array}{l}\text { Solana } \\
\text { Beach }\end{array}$ & $\begin{array}{l}\text { South } \\
\text { Carlsbad } \\
\end{array}$ & $\begin{array}{l}\text { Total } \\
\text { Abundance }\end{array}$ & $\begin{array}{l}\text { Relative } \\
\text { Abundance (\%) }\end{array}$ \\
\hline $\begin{array}{l}\text { Emerita } \\
\text { analoga }(\mathrm{C})\end{array}$ & 65 & 19 & 16 & 14 & 289 & 24 & 212 & 80 & 719 & 28.20 \\
\hline $\begin{array}{l}\text { Talitrid } \\
\text { amphipods (C) }\end{array}$ & 44 & 145 & 0 & 164 & 8 & 4 & 25 & 24 & 414 & 16.20 \\
\hline Scolelepis sp. (P) & 31 & 23 & 101 & 41 & 7 & 19 & 88 & 14 & 324 & 12.70 \\
\hline Donax spp. (B) & 25 & 25 & 4 & 70 & 4 & 31 & 55 & 17 & 231 & 9.04 \\
\hline $\begin{array}{l}\text { Unknown } \\
\text { polychaetes }\end{array}$ & 17 & 15 & 51 & 23 & 5 & 8 & 19 & 7 & 145 & 5.68 \\
\hline $\begin{array}{l}\text { Thoracophelia } \\
\text { spp. (P) }\end{array}$ & 4 & 44 & 83 & 4 & 2 & 1 & 0 & 0 & 138 & 5.40 \\
\hline $\begin{array}{l}\text { Nephtys } \\
\text { californiensis (P) }\end{array}$ & 5 & 11 & 32 & 16 & 6 & 13 & 16 & 11 & 110 & 4.31 \\
\hline $\begin{array}{l}\text { Hemipodia } \\
\text { simplex }(\mathrm{P})\end{array}$ & 7 & 0 & 6 & 17 & 8 & 10 & 32 & 4 & 84 & 3.29 \\
\hline $\begin{array}{l}\text { Naineris } \\
\text { dendritica }(\mathrm{P})\end{array}$ & 13 & 14 & 1 & 22 & 1 & 1 & 20 & 1 & 73 & 2.86 \\
\hline $\begin{array}{l}\text { Orbinia } \\
\text { johnsoni }(\mathrm{P})\end{array}$ & 9 & 11 & 1 & 9 & 5 & 1 & 30 & 5 & 71 & 2.78 \\
\hline Insects & 0 & 0 & 0 & 2 & 0 & 0 & 51 & 0 & 53 & 2.08 \\
\hline Excirolana spp. (C) & 2 & 7 & 14 & 14 & 1 & 2 & 2 & 7 & 49 & 1.92 \\
\hline Nemertea & 5 & 7 & 9 & 10 & 2 & 1 & 5 & 10 & 49 & 1.92 \\
\hline $\begin{array}{l}\text { Unknown } \\
\text { (heavily damaged) }\end{array}$ & 0 & 2 & 8 & 7 & 0 & 0 & 15 & 5 & 37 & 1.45 \\
\hline $\begin{array}{l}\text { Blepharipoda spp. } \\
\text { (C) }\end{array}$ & 2 & 1 & 10 & 3 & 2 & 6 & 2 & 2 & 28 & 1.10 \\
\hline Spionidae (P) & 0 & 3 & 2 & 2 & 0 & 0 & 4 & 3 & 14 & 0.55 \\
\hline Olivella spp. (G) & 0 & 5 & 0 & 0 & 0 & 3 & 0 & 0 & 8 & 0.31 \\
\hline $\begin{array}{l}\text { Unknown } \\
\text { Crustaceans }\end{array}$ & 0 & 0 & 4 & 0 & 0 & 0 & 0 & 0 & 4 & 0.16 \\
\hline Tivela spp. (B) & 1 & 0 & 1 & 0 & 0 & 0 & 0 & 0 & 2 & 0.08 \\
\hline Phialidium spp. (N) & 0 & 1 & 0 & 0 & 0 & 0 & 0 & 0 & 1 & 0.04 \\
\hline
\end{tabular}




\section{Table 3}

Restricted permutation analysis of variance of density (animals per core) of individual taxa and groups of taxa. Factors are treatment (Tr), time since disturbance (TSD), and beach (Be): $* \mathrm{P}<0.05 ; * * \mathrm{P}<$ $0.01 ; * * * \mathrm{P}<0.001$.

\begin{tabular}{|c|c|c|c|c|c|c|c|c|c|c|c|c|c|c|c|}
\hline \multirow[b]{2}{*}{ Factor } & \multicolumn{3}{|c|}{ Total } & \multicolumn{2}{|c|}{$\begin{array}{l}\text { Emerita } \\
\text { analoga }\end{array}$} & \multicolumn{2}{|c|}{ Amphipods } & \multicolumn{2}{|c|}{$\begin{array}{l}\text { Donax } \\
\text { gouldii }\end{array}$} & \multicolumn{2}{|c|}{$\begin{array}{l}\text { Scolelepis } \\
\text { spp. }\end{array}$} & \multicolumn{2}{|c|}{$\begin{array}{l}\text { All } \\
\text { Polychaetes }\end{array}$} & \multicolumn{2}{|c|}{$\begin{array}{l}\text { No Emerita } \\
\text { analoga }\end{array}$} \\
\hline & $\mathrm{df}$ & MS & $\mathrm{F}$ & MS & $\mathrm{F}$ & MS & $\mathrm{F}$ & MS & $\mathrm{F}$ & MS & $\mathrm{F}$ & MS & $\mathrm{F}$ & MS & $\mathrm{F}$ \\
\hline $\mathrm{Tr}$ & 1 & 5.72 & 1.93 & 2.32 & $6.71 * *$ & 0.48 & 1.65 & 0.01 & 0.16 & 0.54 & 2.96 & 6.43 & $7.18^{* *}$ & 15.33 & 9.15* \\
\hline TSD & 3 & 5.73 & 1.43 & 14.08 & $4.48 * * *$ & 0.69 & $2.65 *$ & 0.24 & $4.20 * *$ & 0.33 & 2.93* & 1.80 & $3.47 *$ & 5.81 & $6.42 * * *$ \\
\hline $\mathrm{Be}$ & 7 & 6.06 & 0.96 & 2.87 & 0.93 & 0.66 & 1.94 & 0.12 & 1.79 & 0.26 & 1.08 & 1.44 & 1.32 & 3.57 & 1.71 \\
\hline Tr x TSD & 3 & 4.02 & $5.80 * *$ & 2.03 & $5.00 * *$ & 0.09 & 0.42 & 0.07 & 1.78 & 0.02 & 0.37 & 0.15 & 0.47 & 0.66 & 1.34 \\
\hline $\operatorname{Tr} \times \mathrm{Be}$ & 7 & 2.97 & $4.27^{*}$ & 0.35 & 0.85 & 0.29 & 1.39 & 0.04 & 1.06 & 0.18 & 3.13* & 0.90 & 2.77 & 1.68 & 3.39 \\
\hline $\mathrm{TSD} \times \mathrm{Be}$ & 7 & 4.02 & $5.79 * *$ & 3.14 & $7.74 * *$ & 0.26 & 1.24 & 0.06 & 1.43 & 0.11 & 1.98 & 0.52 & 1.61 & 0.90 & 1.83 \\
\hline $\operatorname{Tr} \times \operatorname{TSD} \times \mathrm{Be}$ & 21 & 0.69 & $2.00 *$ & 0.41 & $2.43 *$ & 0.21 & $5.18 * *$ & 0.04 & $4.83 * *$ & 0.06 & 0.75 & 0.32 & $3.44 *$ & 0.49 & 2.72* \\
\hline Residuals & 64 & 0.35 & & 0.17 & & 0.04 & & 0.01 & & 0.08 & & 0.09 & & 0.18 & \\
\hline
\end{tabular}




\section{Table 4}

Restricted permutation analysis of variance in taxon richness. Factors and significance levels as in Table 3.

\begin{tabular}{lcll}
\multicolumn{4}{c}{ Taxon Richness } \\
\hline Factor & df & MS & F \\
\hline Tr & 1 & 182.88 & $\mathbf{1 0 . 3 3 *}$ \\
TSD & 3 & 51.40 & $\mathbf{6 . 7 4 * *}$ \\
Be & 7 & 18.11 & 0.87 \\
Trx TSD & 3 & 27.55 & $\mathbf{5 . 9 8 * *}$ \\
Trx Be & 7 & 17.70 & $\mathbf{3 . 8 4 *}$ \\
TSD x Be & 21 & 7.63 & 1.66 \\
Trx TSD x Be & 21 & 4.61 & 1.65 \\
Residuals & 64 & 2.79 & \\
\hline
\end{tabular}




\section{Figure 1}

Project map for Regional Beach Sand Project III (RBSP II), with recipient sites indicated by green circles.

\section{Figure 2}

Abundance of common taxa through time at nourished and control beaches, represented by the mean number of individuals per core. The time since nourishment in months is plotted on the $\mathrm{x}$ axis. s $95 \%$ confidence intervals are shown for each census period.

\section{Figure 3}

Density of the two most common groups, Emerita analoga and Polychaetes, through time and by beach.

\section{Figure 4}

Taxon richness through time at nourished and control beaches. 95\% confidence intervals are displayed for each time period.

\section{Figure 5}

NMDS of log-transformed abundance data using a Euclidean distance measure. Species scores for the most abundant taxa and all polychaetes included. Stress $=0.167$.

\section{Figure 6}

Euclidean distance based-NMDS of log-transformed community data, partitioned by time since disturbance. Transects are labeled as abbreviations of source beach. Red labels indicate the transect is from the control portion of that beach, while green labels indicate it is from the nourished portion. PERMANOVA p-values for nourishment, site, and the nourishment-by-site interaction are located in the top right. 


\section{Figure 1}

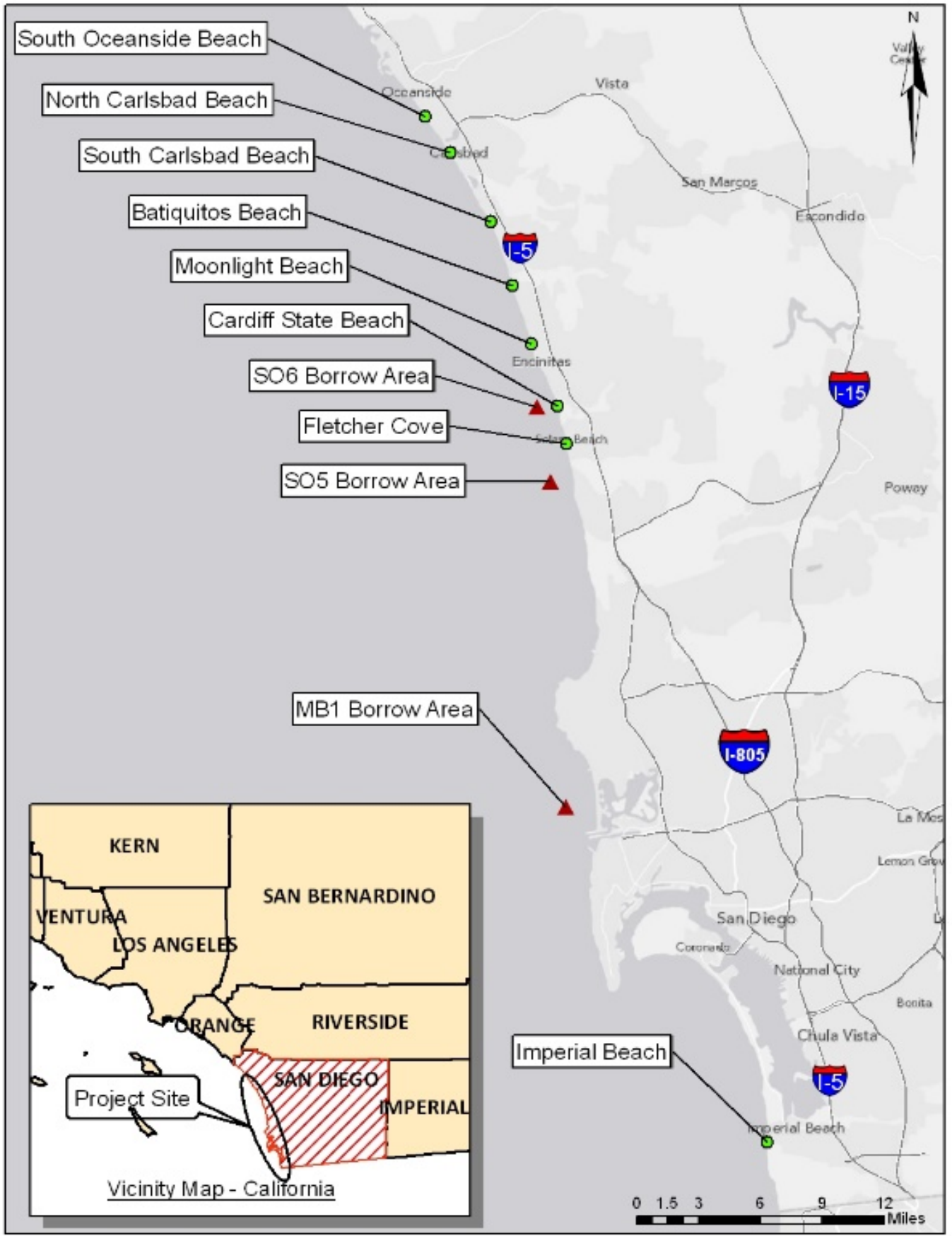

Figure 2 

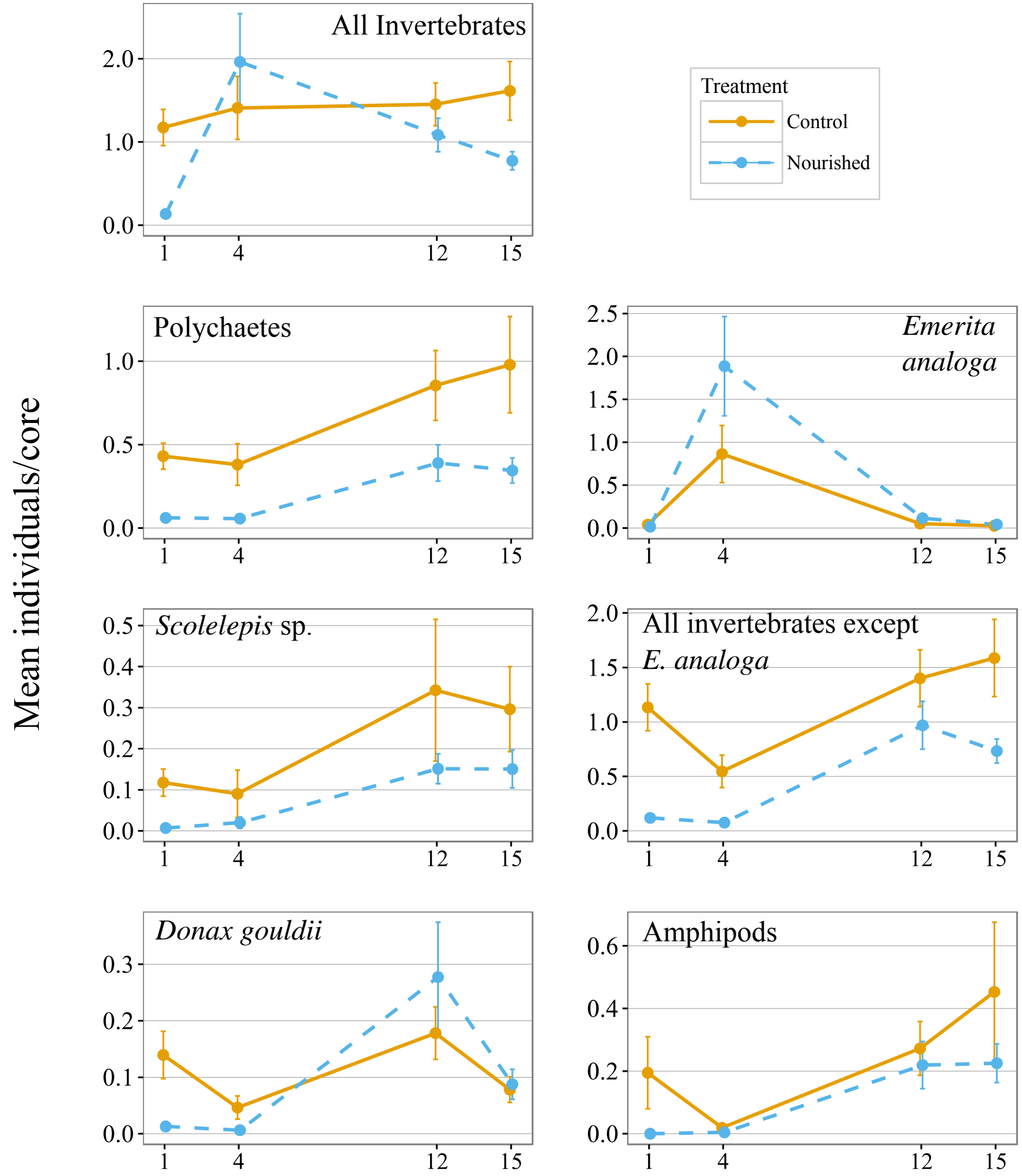

Time since disturbance (months) 


\section{Figure 3}

\section{Polychaetes}

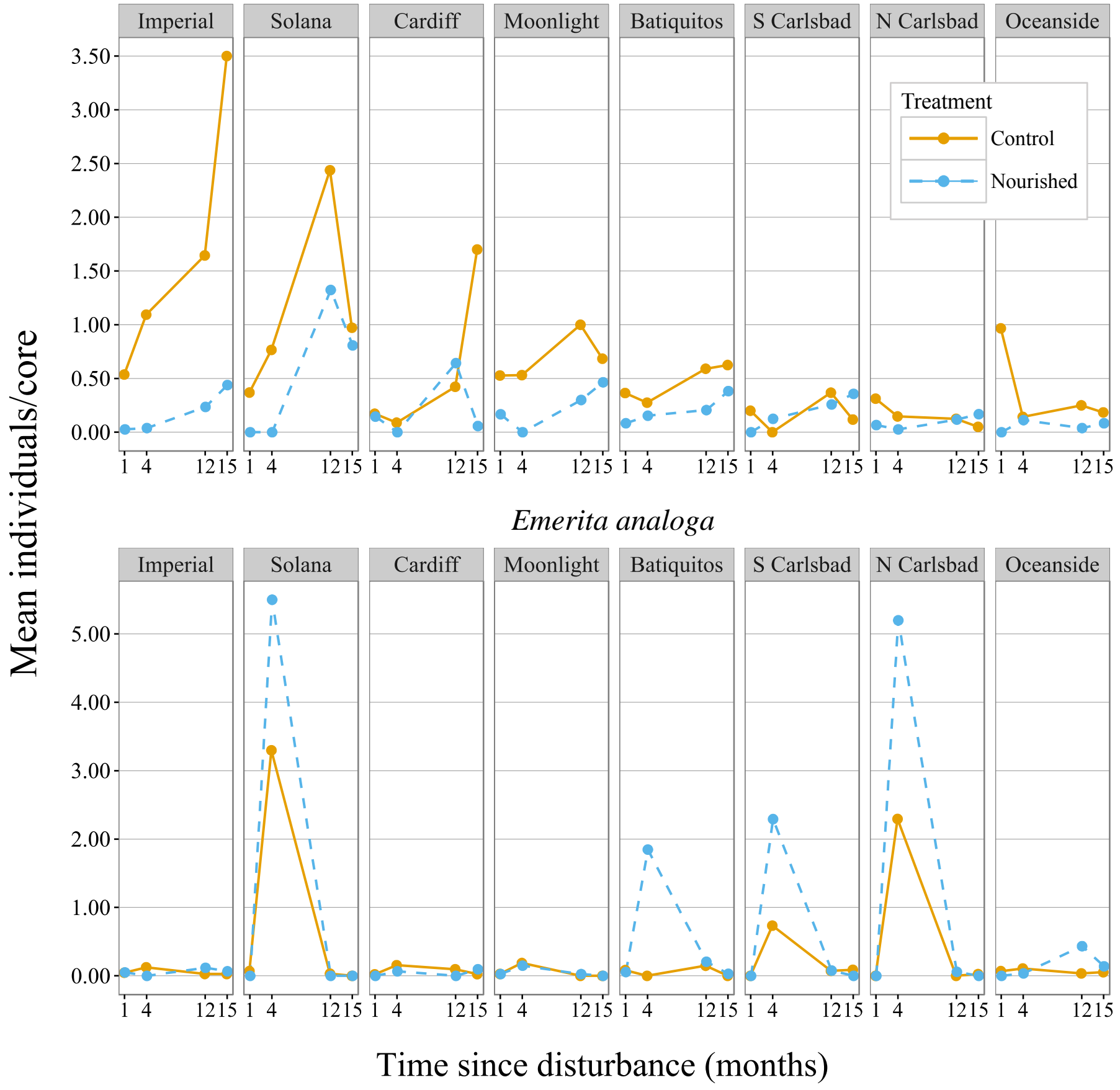




\section{Figure 4}

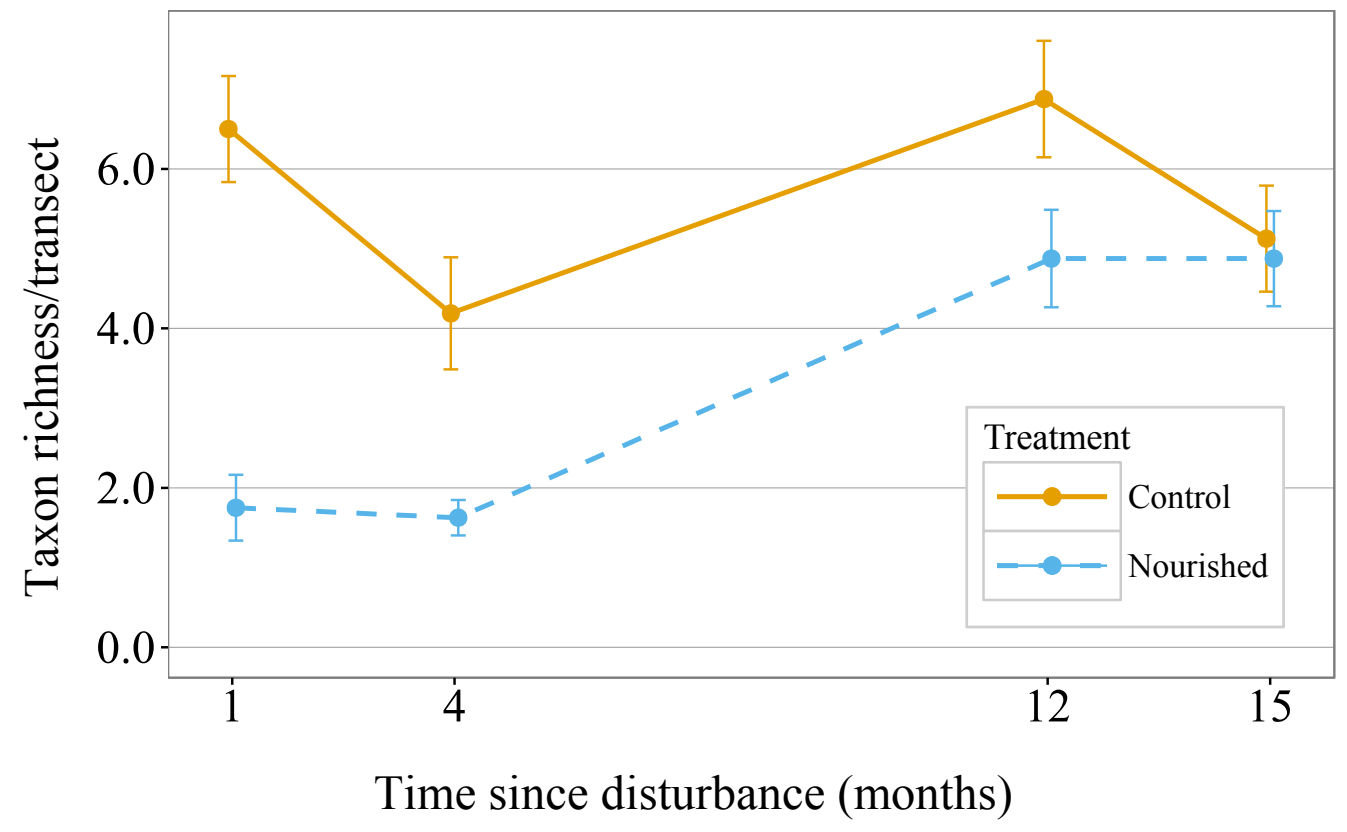




\section{Figure 5}

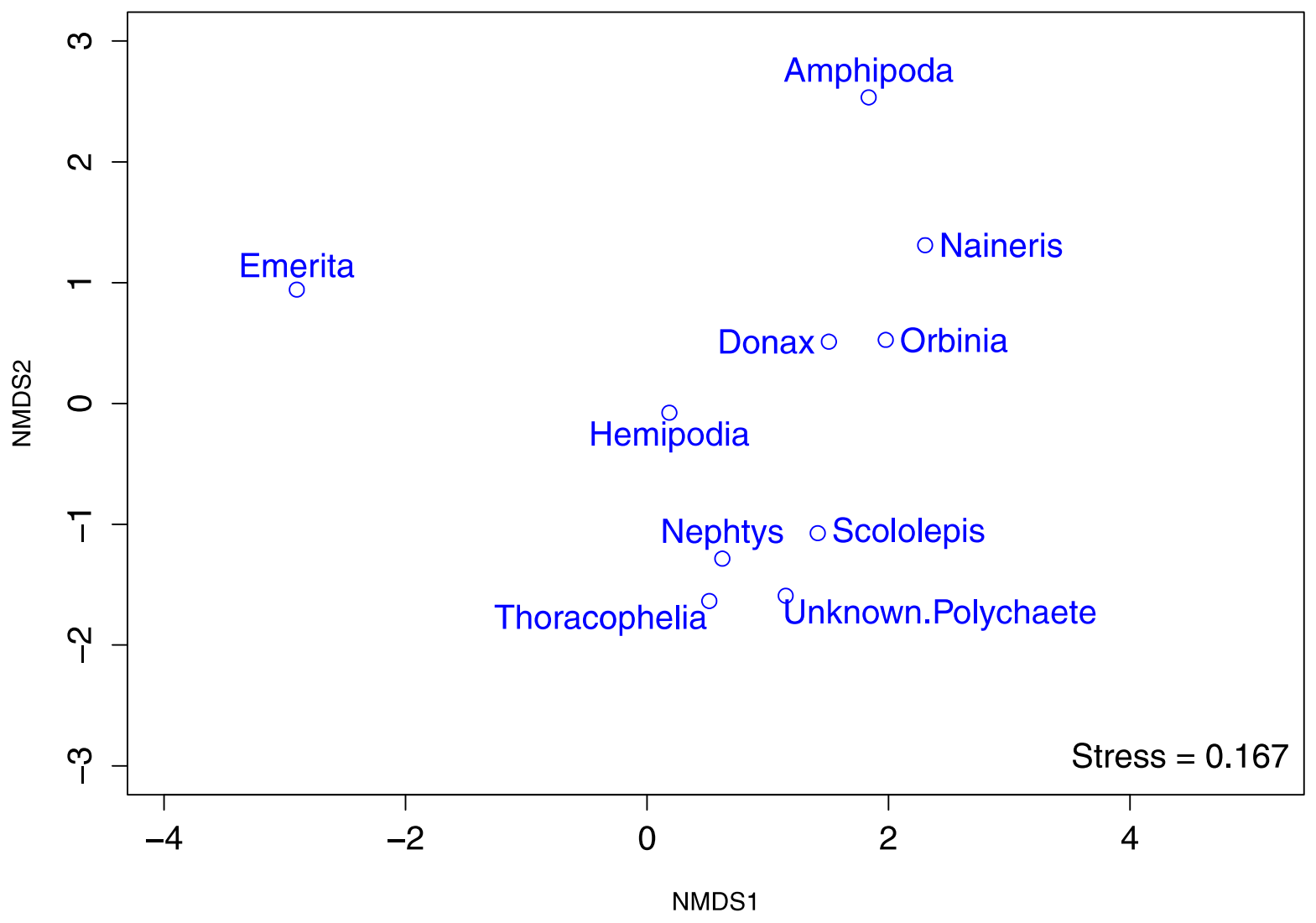




\section{Figure 6}
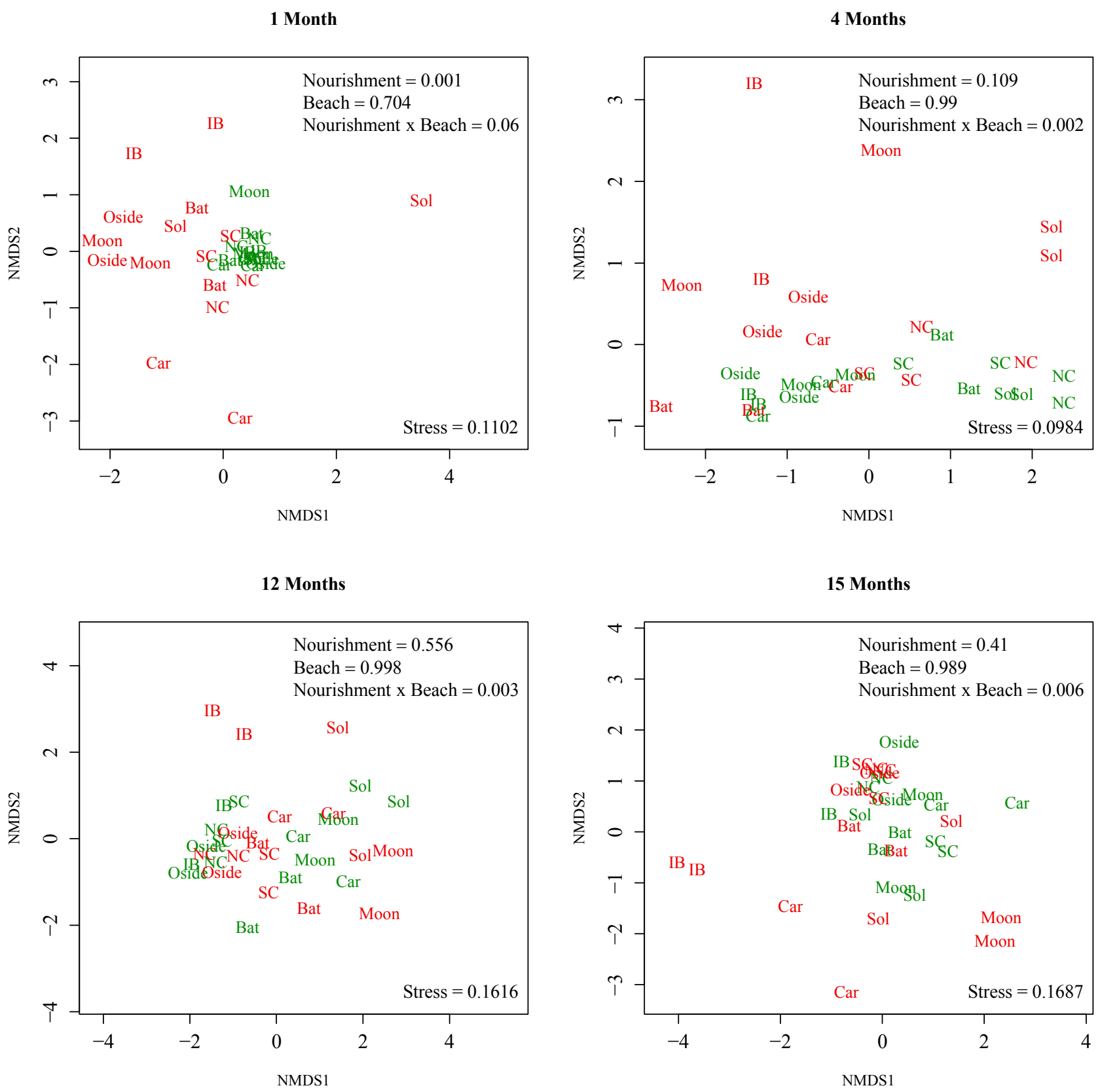

- Control

- Nourished 


\section{No sand (control) \\ Sand added to improve beach}
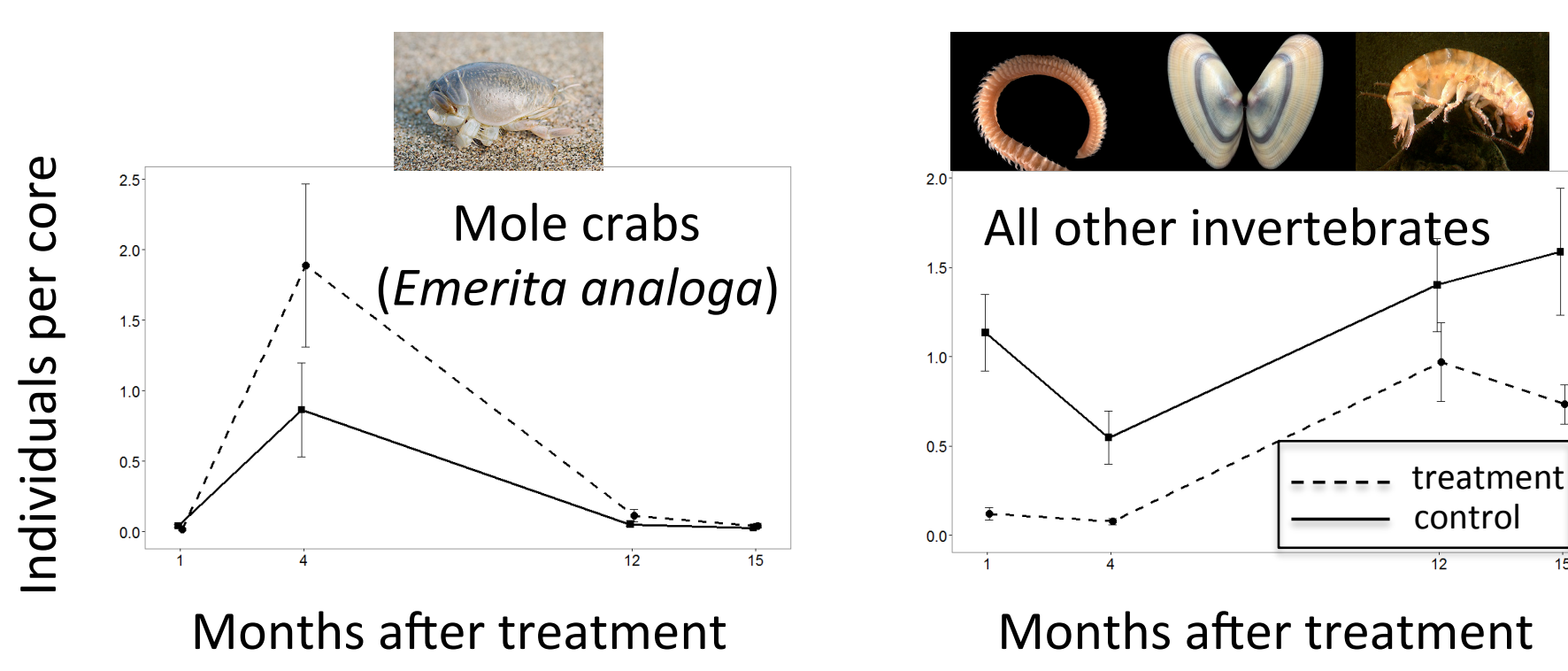

Months after treatment

Months after treatment

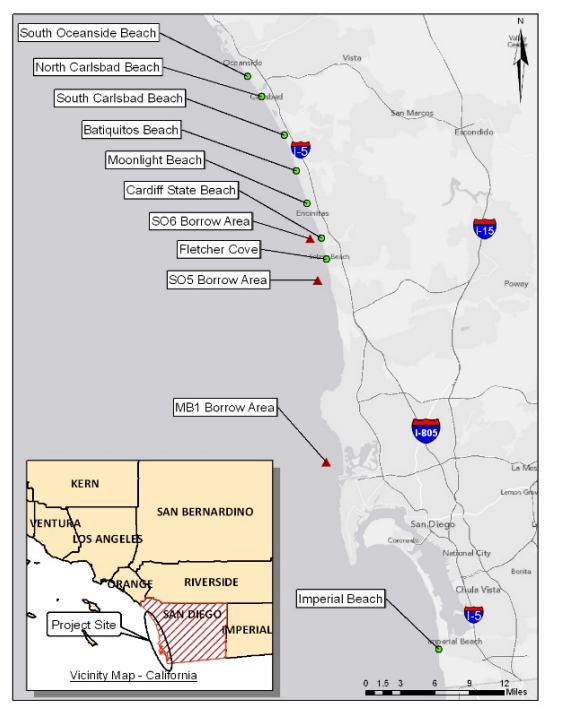

$\mathrm{X} 8$ beaches

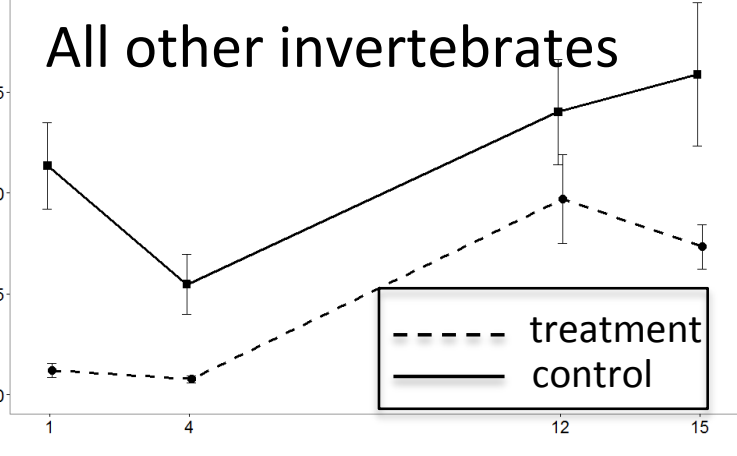

